\title{
Judging the Franks: Proof, Justice, and Diversity in Late Medieval Alexandria and Damascus
}

\author{
FRANCISCO APELLÁNIZ \\ Université Paris 1 (Panthéon Sorbonne), European Research Council
}

By the end of the Middle Ages, the Frankish presence in the Islamic cities of commerce had fashioned a complex legal landscape with a plurality of institutions. Notaries and courts of justice brought by crusaders and Frankish traders coexisted with their Islamic counterparts. Both diaspora historians and economic writers are now intrigued as to whether, and if so to what extent, minorities relied on the available institutional framework or whether they looked first to their "own" courts when seeking justice. From the Jewish merchant community portrayed in the Cairo Geniza letters (eleventh and twelfth centuries) to late Ottoman times, it is now clear that minority legal scholars adopted features of Islamic judicial practice, and that non-Muslims and foreign merchants did not rule out Islamic courts and contracts. ${ }^{1}$ Yet historians know little about the interplay between the Islamic Law and the legal devices carried by Franks to the Middle East, particularly after the Crusades.

The religious character of Islamic law, the $\operatorname{sharl}^{-} a$, and its application in a context characterized by the increasing presence of unbelievers, have stirred many controversial issues, particularly as regards its role in solving mixed disputes. Allegedly, this law was marked by a tendency to respect formalist, religious rules of procedure, such as privileging Muslims as exclusive actors in

Acknowledgments: I would like to express my gratitude to Wolfgang Kaiser, Tijana Krstić, Tamar Herzog, Stéphane Van Damme, Mercedes García-Arenal, Maribel Fierro, and Yavuz Aykan for their invitations to discuss these arguments and for their comments. This research was funded by the Project Mediterranean Reconfigurations (ConfigMed) (Advanced Grant no. 295868-European Research Council).

1 For a recent reassessment on the Geniza Merchants, see Jessica Goldberg, Trade and Institutions in the Medieval Mediterranean: The Geniza Merchants and Their Business World (Cambridge: Cambridge University Press, 2012), 150-79. As for non-Muslims' recourse to royal courts, Marina Rustow, "The Legal Status of Dhimmis in the Fatimid East: A View from the Palace in Cairo," in Maribel Fierro and John Victor Tolan, eds., The Legal Status of Dhimmis in the Islamic West (Turnhout, Belgium: Brepols, 2013), 307-32. Mark R. Cohen, "A Partnership Gone Bad: Business Relationships and the Evolving Law of the Cairo Geniza Period," Journal of the Economic and Social History of the Orient 56 (2013): 218-63. 
the legal system. By contrast, scholarship on late medieval European law highlights very different aspects. According to legal historians, Western legal systems were far from formalist and broke with previous oral and irrational systems of proof (such as the medieval ordeal). They gave birth to new merchant courts and granted summary, less stringent procedures for foreigners and merchants. Moreover, the law did not exhibit the same biases towards unbelievers, who could pronounce oaths, present evidence, and bear witness more freely. ${ }^{2}$

Were these two legal spheres kept separated in the thriving Mediterranean ports? Did they, instead, complement each other in order to provide a means of settling mixed disputes? Traditional scholarship has suggested that they simply coexisted, and that the primary locus of legal interaction was the occasional acceptance of each other's proofs. ${ }^{3}$ But was there room for more practical collaboration, particularly in disputed areas such as the participation of unbelievers as actors in the legal process and the validation of proof and evidence? By describing the way witnessing, oaths, and proof were handled in mixed cases, and the role of notarial institutions before, during, and after these trials, I will challenge the essentialist view of two opposed normative systems, where an Islamic one exhibited biases that would have limited exchanges. My focus will be on two different, yet neighboring legal institutions that played their part in underpinning exchanges across boundaries. The first is the notaries sent to Alexandria and Damascus by the Venetian government to draw up legal documents and to support the transactions of Venetian merchants. The second institution is the new royal courts implemented by the Mamluk sultans in these two cities, where justice was rendered by government officials and not by qā $d \bar{\imath} s$. Although both institutions were by-products of very different historical and juridical backgrounds, the problems faced by judges and notaries were nonetheless of a similar nature: what was to be accepted as trustworthy and what as proof? Could an oath or eyewitness testimony from an unbeliever be considered valid? What about from a renegade? Could their contracts be considered public and probative acts?

The privileges granted by medieval Islamic rulers allowed consuls and minority merchants to arbitrate disputes between their peers, but when a Muslim was involved, the case was adjudicated in an Islamic court, where, for instance, Frankish litigants could not make use of Christian witnesses to support their

2 Fredric L. Cheyette, "Suum cuique tribuere," French Historical Studies 6, 3 (1976): 287-99. For an recent overview on late medieval commercial courts, see M. Fusaro, "Politics of Justice/Politics of Trade: Foreign Merchants and the Administration of Justice from the Records of Venice's Giudici del Forestier," Mélanges de l'École française de Rome-Italie et Méditerranée modernes et contemporaines 126, 1 (2014), 21 July 2014, http://mefrim.revues.org/1665 (accessed 8 Sept. 2014). Minority witnessing in Genoa and Venice is discussed below.

3 Dominique Valérian, "Le recours à l'écrit dans les pratiques marchandes en contexte intercultural: Les contrats de commerce entre chrétiens et musulmans en Méditerranée," in L'autorité de l'écrit au moyen âge: orient-occident: XXXIXe congrès de la SHMESP, Le Caire, 30 avril-5 mai 2008 (Paris: Publications de la Sorbonne, 2009), 68-72. 
claims. A recent, influential book by Timur Kuran presents foreign privileges as facilitators of modern, impersonal exchanges, as against the formalism of Islamic law and its legal biases against non-Muslims, which are counted among the major "structural inefficiencies" that hampered the economic modernization of Islamic countries. ${ }^{4}$ This article deals with two of these major procedural obstacles and the ways notaries and courts labored to thwart their negative effects. The first is the $\operatorname{shari~}^{-} a$ approach to proof, which denies the ultimate legal value of written and other "circumstantial" evidence. ${ }^{5}$ According to the epistemological skepticism of classical jurists, only God knows the truth and, since deeds can be falsified, the judge may rely on the utterances of trustworthy, male Muslims at court. Witnesses' commitment to Islam, it is argued, may ensure the veracity of their statements. A second, related bias, concerns the exclusion of non-Muslims as actors in the legal system. Shāfi'ī, Hanbalī, and Mālikī schools of law prevented nonMuslims from serving as witnesses either in the courtroom or before a notary. The Hanafis allowed local Christians and Jews to testify, but only for and against their coreligionists. The debate among economists and historians on the biases of Islamic justice has gained momentum around the adjudication system in the late Ottoman period. The controversial "jurisprudential shift hypothesis" holds that eighteenth-century Ottoman authorities sold access to European courts to non-Muslims so that they could benefit from the superior conditions of trade offered by the European institutions. ${ }^{6}$ But unlike in the late Ottoman world depicted by Kuran, where merchants switched to Western legal institutions as soon as they could, during medieval times Muslims and nonMuslims had no choice but to solve their disputes without challenging the supremacy of the $\operatorname{shari~}^{-} a$. In this essay, my aim is not to challenge Kuran's theses, but rather to search out medieval Islamic judicial practice for more open attitudes toward non-Muslims and the settling of mixed disputes.

To this end, Muslims and Franks could rely on new legal agents that appeared in the dynamic context of the mid-fourteenth century. The Venetians started to run regular convoys to Syria and Egypt in the 1340s, and this is when the first consular notaries appear in the archives. ${ }^{7}$ As for the royal

\footnotetext{
4 Timur Kuran, The Long Divergence: How Islamic Law Held Back the Middle East (Princeton: Princeton University Press, 2010).

5 Brinkley Messick, The Calligraphic State: Textual Domination and History in a Muslim Society (Berkeley: University of California Press, 1993), 203-31; and Jeanette A. Wakin, The Function of Documents in Islamic Law: The Chapters on Sales from Tahāwī̀s Kitāb al-Shurūt al-Kabīr (Albany: State University of New York Press, 1972), 1-70; A. L. Udovitch, "Les échanges de marché dans 1'Islam médiéval: théorie du droit et savoir local," Studia Islamica 65 (1987): 5-30, 24-25.

6 Kuran, The Long Divergence, 198-202. Ottomanists have, nonetheless, challenged Kuran's theses, Maurits H. Van den Boogert, "Legal Reflections on the "Jurisprudential Shift Hypothesis," Turcica 41 (2009): 373-82.

7 E. Ashtor, Levant Trade in the Later Middle Ages (Princeton: Princeton University Press, 1983), preface; Georg Christ, Trading Conflicts: Venetian Merchants and Mamluk Officials in Late Medieval Alexandria (Leiden: Brill, 2012), 78-79.
} 
courts, the role played by royal justice under the Mamluks has been identified as an important shift in the history of Islamic Law. The courts of the $q \bar{a} d \bar{l} s$, where $\operatorname{shari~}^{\mathrm{c}} a$ was applied according to traditional jurisprudence, with complex rules of procedure, had been supplemented by more expedient courts since early Islamic times. The best known of these royal jurisdictions were the mazalim, in whose courts the ruler theatrically displayed his justice and gave verdicts according to his own judgment. In this article I will be dealing with a similar royal jurisdiction that was derived from the mazālim and frequently overlapped with it. It comprised the siyassa, where justice was administered by the chamberlain ( $h \bar{a} j i b)$ and other military officers such as the head emir in Alexandria. ${ }^{8}$

Contemporaries believed that the term siyāsa derived from a lost legal code imported from Asia. We know now that it had its origins in a lost Arabic root meaning "the tending and training" (of beasts). Siyāsa is commonly translated as "politics," sometimes rendered as "governance" or "statecraft." The conceptual world of the jurists ideally harmonized siyāsa shar $\bar{y} y a$, a legal theory of governance, and the general rule of law, or $\operatorname{sharit}^{-} a{ }^{9}$ This was a more troublesome thing to do for Mamluk judges, sultans, and officials, who, as Mamluk chronicles show, daily entered into conflict with qādis while administering justice. ${ }^{10}$ Regarded with suspicion by both contemporaries and historians, Mamluk siyāsa is now stirring a vivid scholarly debate, perhaps due to its growing importance in the later modernization of Islamic law. The debate on siyassa has revolved around the question of whether it was compliant with religious law, was new or old, secular or not, or just a tool of political legitimacy for the sultans. ${ }^{11}$ Important works by Baber Johansen on the disciples of Ibn Taymīyah (d. 1328) have underlined the efforts of siyāsa thinkers to

${ }^{8}$ For the mazālim and the Islamic judiciary, see Wael B. Hallaq, "Islamic Law: History and Transformation," in The New Cambridge History of Islam, vol. 4 (2010), 158-62. For Mamluk siyāsah, see Albrecht Fuess, "Zulm by Mazālim? The Political Implications of the Use of Mazālim Jurisdiction by the Mamluk Sultans," Mamluk Studies Review 13 (2009): 121-47; R. Irwin, "The Privatization of "Justice" under the Circassian Mamluks," Mamluk Studies Review 5 (2002): 63-70; Jørgen S. Nielsen, Secular Justice in an Islamic State: Mazālim under the Bahrī Mamlūks, 662/1264-789/1387 (Leiden: Nederlands Historisch-Archaeologisch Instituut te Istanbul, 1985); Yossef Rapoport, "Royal Justice and Religious Law: Siyāsah and Shari'ah under the Mamluks," Mamluk Studies Review 15 (2012): 71-102.

9 On late medieval siyāsah, see Ann K. S. Lambton, State and Government in Medieval Islam: An Introduction to the Study of Islamic Political Theory: The Jurists (New York: Routledge/Curzon, 1981) 138-52. For the origins, meaning, and different perceptions of the term, see F. E. Vogel, "Siyāsah," in C. E. Bosworth et al., eds., The Encyclopaedia of Islam, 2d ed. (Leiden: Brill, 1997), vol. 9, 693-96; and Bernard Lewis, "Siyasa," in A. H. Green, ed., In Quest of an Islamic Humanism: Arabic and Islamic Studies in Memory of Mohamed al-Nowaihi (Cairo: American University in Cairo Press, 1984).

10 Rapoport, "Royal Justice," 100-1; Irwin, "Privatization," 66.

11 The debate has been thoroughly addressed by Rapoport, "Royal Justice," 73-80. On the doctrinal similitudes with mazālim, see Fuess, "Zulm by Mazālim?," 132, 141; Nielsen, Secular Justice, 32 . 
overcome the limitations of justice administered by $q \bar{a} d \bar{l} \bar{\imath} s$, particularly in the field of proof and evidence, the question at issue here. ${ }^{12}$ This article follows this line if inquiry by exploring the role of Mamluk siya $a s a$ as judicial practice, focusing on hitherto unknown aspects and scenarios, namely its role in settling mixed commercial disputes in the Mediterranean cities of commerce.

I begin with the narrative, from a Muslim viewpoint, of how siyāsa courts started to pass judgment over foreign merchants. In the second section I proceed to a comparative account of the differences and similarities presented by Islamic and Western notaries at work in the markets and, as we will see, also at court. A comparative approach may help us understand how they coexisted for almost two centuries in Alexandria and Damascus, and how their different approaches to proof made them complementary rather than opposing or alternative devices. In the third section I outline the way Latin notaries operated in the Middle East and how they dealt with Islamic customers, witnesses, oaths, and the legal documents they produced to justify their claims. A longer, final section describes how merchants shopped the courts, including the siyāsa tribunals, and the role played by Latin clerks in the judicial process.

\section{$S I Y \bar{A} S A$ JUSTICE IN THEORY AND PRACTICE}

In spite of the recent interest in siyāsa, its jurisdiction over foreigners has gone almost totally unnoticed. We knew that mixed disputes were dealt with by some sort of royal justice, yet only an imperceptible legal change from mazālim to siyāsa can explain the exact nature of these courts. Siyāsa found its way into mixed cases through the "piecemeal modification of particular aspects of the law" and the articulation of new doctrine in fatwas and commentaries demanded by "new circumstances." "13 To further complicate things, siyāsa court proceedings have disappeared, and trials can only be reconstructed through descriptions provided by the Franks to their own notaries. The courts of the $h \bar{a} j i b s$ existed until the mid-fourteenth century as a special jurisdiction administering justice among the military. Before that, the numerous bilateral treaties that regulated the activities of the Frankish traders make no mention of the $h \bar{a} j i b s$. Treaties signed before the 1360 s allowed the $q \bar{a} d \bar{l} \bar{s}$ to adjudicate disagreements between Muslims and Christians, while the right to appeal directly to the sultan's mazālim court in Cairo was always recognized. ${ }^{14}$

12 Baber Johansen, "Signs as Evidence: The Doctrine of Ibn Taymiyya (1263-1328) and Ibn Qayyim al-Jawziyya (d. 1351) on Proof," Islamic Law and Society 9, 2 (2002): 168-93; Baber Johansen, "Vérité et torture: Ius commune et droit musulman entre le Xe et le XIIIe siècle," in Françoise Héritier, ed., De la violence (Paris: Odile Jacob, 1996).

13 Hallaq, "Islamic Law," 171; and Rapoport, "Royal Justice," 73.

14 In early treaties the $h \bar{a} j i b$ is never mentioned, while the $q \bar{a} d \bar{\imath}$ clearly adjudicates, Kate Fleet, "Turks, Mamluks, and Latin Merchants: Commerce, Conflict, and Cooperation in the Eastern Mediterranean," in Jonathan Harris, Catherine J. Holmes, and Eugenia Russell, eds., Byzantines, Latins, and Turks in the Eastern Mediterranean World after 1150 (Oxford: Oxford University Press, 2012), $340-41$. The treaty with Genoa of 1271 foresees that in some circumstances "the case was to be 
However, according to the Arab historian Taqī al-Dīn al-Maqrīzī, an episode in 1352-1353 triggered an expansion of siyāsa jurisdiction to the affairs of foreigners. According to this famous passage, some Persian merchants arrived in Egypt fleeing mistreatment by the Mongols. They struck a business deal in Cairo with local merchants that turned bad. The Persians then appealed to the hanafi $q \bar{a} d \bar{l}$, but the defendants found a loophole in the hanafi bankruptcy regulations and managed to get away with their debts. The hanafi school prescribed the imprisonment of defaulters, and it seems that the Cairo merchants were ready to spend time in detention before they were declared bankrupt so they would not have to pay. In other words, shari $^{-} a$ regulations on bankruptcy prevented the plaintiffs from obtaining a satisfactory verdict. However, the Persians complained to the sultan, who for the first time handed the case to the royal courts. The hajjib, in turn, punished the Cairene merchants and forced them to pay their debts. They were acting according to juridical doctrines such as the Siyāsa Shar 'iya- - "Governance according to Islamic Law" - of Ibn Taymīyah, which recommended that the sultan inflict corporal punishments on defaulters who were, we must imagine, hiding their wealth. This first intervention on issues of debt backed by the sultan himself, al-Maqrīzī argues, became a precedent. ${ }^{15}$

A second episode, not hitherto linked with al-Maqrīzī's story of the Persian merchants, helps us to understand how the problem of foreigners was being handled by Mamluk jurists. In April 1353, the shāfi ' $\bar{l}$ jurist Taqī al-Dīn al-Subkī granted a legal opinion (fatwa) on a similar topic regarding the juridical situation of some Frankish merchants in Acre. The merchants, according to the petitioner, a provincial governor, had gone beyond the terms of their agreements as they had started to publicly celebrate religious ceremonies that offended local Muslims (apparently, they hired Muslim porters during a procession). In his response to the consultation, al-Subkī placed all jurisdiction over foreign merchants in the sultan's hands, not in those of the $q \bar{a} d \bar{c} s$; it was the ruler and his agents who enjoyed discretionary power to punish offenders in

brought before the Muslim judge (archadi; i.e., al-qād $\bar{\imath}$ )"; P. M. Holt, Early Mamluk Diplomacy, 1260-1290: Treaties of Baybars and Qalāwün with Christian Rulers (Leiden: Brill, 1995), 14546. Similarly, in the treaty of 1303 some disputes are settled by the qādi: questio oriretur, debeat diffiniri per cadhy terre; G. M. Thomas and R. Predelli, Diplomatarium veneto-levantinum sive acta et diplomata res venetas graecas atque levantis illustrantia, vol. 1 (Venice: Deputazione veneta di storia patria 1880), 7. The same is found in article 22 of the Mamluk-Venetian treaty of 1345: tunc uenditor et emptor debeant ire ad rationem coram el cadi; ibid., 295. This does not contradict the general right to appeal to the sultan's mazălim, invariably mentioned in Ayyubid, Mamluk, and Ottoman treaties.

${ }^{15}$ Aḥmad ibn 'Abd al-Ḥalīm Ibn Taymīyah, al-Siyāsah al-shar'īyah fì iṣlāh al-rā' wa-al-ra' ìyah, 'Alī ibn Muhammad 'Umrān, ed. (Mecca: Dār 'Ālam al-Fawā'id, 1429 H), 60. Ahmad Ibn 'Ali al-Maqrizi, Kitāb al-Mawā'iz wa-al-i'tibār fì dhikr al-khitat wa-al-āthār (Cairo: Maktabat al-Thaqafa al-Diniyya, n.d.), vol. 2, 220-22; Rapoport, "Royal Justice," 82-83; Irwin, "Privatization," 66. 
this case, since their offence was not clearly specified by $\operatorname{sharī}^{\mathrm{c}} a .{ }^{16} \mathrm{Al}-\mathrm{Subk} \overline{\mathbf{1}}$, who had been appointed one of the first official legal advisors of the siyāsa courts in Damascus, was inspired by the theories of governance championed by Ibn Taymiyah and his disciples, which regulated the application of discretionary punishment $\left(t a^{c} z \bar{i} r\right)$ by the ruler. ${ }^{17}$

In 1370, al-Subkî's son Abu-l-Barakāt, who followed his father as legal advisor at the royal courts, enriched the text with a commentary on the juridical situation of Franks. The latter, legally enemies of Islam, could enter the realm of Islam for trading purposes upon acceptance of a pact. The basic legal concept here is that any foreign merchant in Islamic lands could benefit from a safeconduct ('amān) protecting his life and property for a limited period. Outside this protection framework (for instance, when it expired or when its terms were broken) the 'amān holder lost his legal status as a musta'min, or protected foreigner, and in consequence any tax or extraterritoriality privileges, such as consular jurisdiction, expired. While from a European viewpoint commercial privileges constituted the main scope of these treaties, for the Muslim authorities they were also the instrument that solved the juridical dilemma of the European presence in Islamic lands, providing merchants with a clear legal personality and settling jurisdictional issues. Together with other prerogatives, treaties included recognition of European consulates and consular courts for issues among Franks. Government-sponsored jurists like the Subkīs took the issue of the Franks' safe-conduct very seriously, placing the presence of Frankish merchants in the sphere of the public interest (mașlahat al-Isläm) and stating that officers, not $q \bar{a} d \bar{c} s$, had jurisdiction over issues concerning their legal status. In so doing, they were opening the door for action by royal courts over these disputes. ${ }^{18}$

On doctrinal grounds, it would be a mistake to trace a divide between siyāsa and preceding versions of Royal justice, such as the mazālim sessions

16 Aziz Atiyya, "An Unpublished XIVth Century Fatwa," in W. Heffening, P. Kahle, and W. Kirfel, eds., Studien zur Geschichte und Kultur des Nahen und Fernen Ostens (Leiden: Brill, 1935); Taqī al-Dīn 'Alī ibn 'Abd al-Kāfī al-Subkī, Fatāwā al-Subkī, Ḥusām al-Dīn Qudsī, ed., 2 vols. $(1355 \mathrm{H})$, vol. $2,417-21$.

17 On Ibn Taymīyah and ta'zīr, see Muhammad Khalid Masud, "The Doctrine of Siyāsah in Islamic Law," Recht van de Islam 18 (2001): 1-29, 11. On discretionary punishment, see Joseph Schacht, An Introduction to Islamic law (Oxford: Clarendon Press 1982), 175-87; and W. Heffening, "Ta'zīr," in The Encyclopaedia of Islam, 2d ed., P. J. Bearman et al., eds. (Leiden: Brill, 2000), vol. 10, 406.

18 Joseph Schacht, "Amān," and "'Ahd," in The Encyclopaedia of Islam, 2d ed., H.A.R. Gibb et al., eds. (Leiden: Brill, 1986), vol. 1, 429-30, and 255, respectively. John Wansbrough, "The SafeConduct in Muslim Chancery Practice," Bulletin of the School of Oriental and African Studies 34, 1 (1971): 20-35. On Mamluk jurists and the idea of public interest, see Michael A. Cook, Commanding Right and Forbidding Wrong in Islamic Thought (Cambridge: Cambridge University Press, 2000), 151-56; Masud, "Doctrine of Siyāsah"; and Fauzi M. Najjar, "Siyasa in Islamic Political Philosophy," in George F. Hourani and Michael E. Marmura, eds., Islamic Theology and Philosophy: Studies in Honor of George F. Hourani (Albany: State University of New York Press, 1984), $92-110$. 
delivered in Cairo by the sultans. As a theory, siyāsa has precedent in the much older doctrine of mazālim, and its development in late medieval times by Hanbalī and Māliki thinkers is therefore uncontroversial. ${ }^{19}$ But if we focus on legal change instead of looking for precedent, the hajjib's court appears as an "expansion of royal jurisdiction," "parallel to the shari'ah courts of the qadis." ${ }^{20}$ Though late Mamluk treaties signed with Florence, Genoa, Venice, and Barcelona have attracted a good deal of attention, the mid-fourteenth-century shift toward siyāsa has not been fully understood. The real novelty brought about in Mamluk times happened in the field of judicial practice: fifteenth-century treaties ruled the jurisdiction of the $q \bar{a} d \bar{c} s$ definitely out of mixed issues, even as a court of appeal. Agreements started to include clauses according to which mixed trials should be heard by "the viceroy or chamberlain $(h \bar{a} j i b)$ or officials of the province, and none other than the above-mentioned should adjudicate between them."21

There is another aspect that makes siyāsa look different from previous forms of royal justice. Appealing to the mazālim courts, set by the sultans in most cases in the capital city, is a right as old as political Islam and is more or less explicitly stated in every 'amān granted by a respectful sovereign. But going to Cairo or wherever the sultan delivered his justice represented a burden that could be abused by local merchants. Muslim plaintiffs sued Franks but did not deign to show up at court later in Cairo. Mazālim was therefore a cause of "damage" ('̇arāma) and "difficulty" (mashaqqa), and Frankish negotiators lobbied to avoid the sultans' court in Cairo in mixed cases. ${ }^{22}$ Mazālim had generally been considered as a court of appeal, a board for grievances committed by officials and unjust decisions made by $q \bar{a} d \bar{\imath} \bar{s}$. Mamluk siyāsa differed, in practical terms, from mazālim in that it gave Franks the right to be heard on the spot by an official applying less stringent procedures than those adopted by $q \bar{a} d \bar{c} s$. It circumvented the action of $\operatorname{sharit}^{-} a$ courts and made an eventual recourse to mazālim unnecessary.

This legal change should not be interpreted as the mere substitution of the $q \bar{a} d \bar{l}$ courts and their $\operatorname{shar}^{\prime} a$-based norms with new "secular" ones. Rather, Mamluk jurists were providing rulers with the necessary legal space to manage the political realities of the European presence. Works endorsing Siyāsa Shar'iya justified the existence of civil judges, not only $q \bar{a} a \bar{l} \bar{s}$, in the community, who could administer justice based on state interest, and not just

19 Johansen, "Vérité et torture."

20 Rapoport, "Royal Justice," 75, 101.

21 John Wansbrough, "Venice and Florence in the Mamluk Commercial Privileges," Bulletin of the School of Oriental and African Studies 28, 3 (1965): 483-523, 488 (Mamluk-Venetian treaty of 1442), and 512 (Mamluk-Florentine treaty of 1497).

${ }^{22}$ M. Amari, I diplomi arabi del R. Archivio Fiorentino (Florence: Le Monnier, 1863), see the treaty of 1496, ch. 10,192, and the negotiations in 1488, ch. 11, 377: per dare disagio et sconcio a merchanti fiorentini. 
on traditional jurisprudence. ${ }^{23}$ According to siyassa theorists, the ruler and his delegates should sit in judgement and deliver physical punishments not according to any exceptional power but rather for the benefit of the community, all issues explicitly mentioned in both al-Subkī's fatwa on Acre and al-Maqrīzī's story of the Persian merchants. "The Imam" al-Subkī states, "can deal with them [the Franks] not depending on his pleasure, but on what seems to be for the good of Muslims." 24 As can be inferred from the spirit of the new 'amān treaties, dealing with Frankish traders fell within the imperatives of governance, and the royal courts were to pass judgment on their affairs. The Mamluk government proceeded with the parallel development of royal courts in Damascus, Aleppo, Cairo, and Tripoli, with state-appointed muftīs and its own hierarchy of hâjibs, thus expanding siyāsa jurisdiction in criminal law and also in civil cases, away from the jurisdiction of the $q \bar{a} d \bar{\imath} s^{25}{ }^{25}$ Its practical implementation and geographic coverage outside Cairo made Mamluk siyāsa appear fundamentally different from previous versions of royal justice. Moreover, siyāsa judges were granted jurisdiction over the judiciary. ${ }^{26}$ They prosecuted $q \bar{a} \underline{d} \bar{l} s$ who embezzled from charitable trusts or in cases where favoritism led to the appointment of colleagues who were "ignorant of the law." As most Mamluk chroniclers belonged to the same religious establishment as the $q \bar{a} d \bar{l} \bar{s}$, there is straightforward resentment against siyāsa in many of our sources. In one case, the historian Ibn al-Himșī was arrested in the course of a $h \bar{a}$ jib investigation. Siyāsa judges set up their own detention facilities and further quarrels emerged regarding the jail in which a detainee should be kept. The prison conditions, at least for the Frankish merchants, seem to have been relatively fair. According to Ibn Ṭūlūn (d. 1546), who had no sympathy for the new parallel judiciary, Franks could even drink wine in the $h \bar{a} j i b$ prison of Damascus. $^{27}$

23 Anver M. Emon, Religious Pluralism and Islamic Law: "Dhimmīs" and Others in the Empire of Law (Oxford: Oxford University Press, 2012), 179-83; Johansen, "Signs as Evidence," 186.

24 The delegates' ( $n \bar{a}$ 'ib) responsibility, punishment (ta'zīr), and public good (mașlahat al-muslimīn) are explicitly addressed by al-Subkī, Atiyya, "An Unpublished XIVth Century Fatwa," 60, 65-66. Maqrīzī insists also on punishment, but instead uses the term 'āqabahum.

25 Archivio di Stato di Venezia (hereinafter ASV), Giudici di Petizion, reg. 98, f. 151v, mentions a trial in Tripoli before the häjib: davanti lazebo.

${ }^{26}$ The function is described in a chancery manual for Mamluk secretaries (ca. 1450), traditionally attibuted to Bahā' al-Dīn al-Khālidī, al-Maqșad al-rafì' al-munšā' al-hādì li-șinā 'at al-inšā', Paris, BNF, Arabic 4439, f. 126, 144.

27 Aḥmad ibn Muḥammad Ibn al-Himșī, Hawādith al-zamān wa-wafayāt al-shuyūkh wa-al-aqrān, 'Umar Tadmurī, ed., 3 vols. (Saydā: al-Maktabah al-'Așrīyah, 1999), vol. 2, 201, 212, 220, 227; Aḥmad ibn Muhammad Ibn Ṭawq, al-Ta'līq: yawmīyāt Shihāb al-Dīn Ahmad ibn Tawq, 834-915 H/1430-1509 M: mudhakkirāt kutibat bi-Dimashq fì awākhir al-'ahd al-Mamlūkī, 885-908 H/1480-1502 M, Ja'far Muhājir, ed. (Damascus: IFEAD, 2000), 119; Shams al-Dīn Muhammad ibn 'Alī Ibn Ṭūlūn, I'lām al-wará bi-man wulliya nāiban min al-atrāk bi-Dimashq al-Shām al-kubrá, Muhammad Aḥmad Dahmān, ed. (Damascus: Wizārat al-Thaqāfah 1964), 117; '196 ibn Yūsuf al-Bușrawī, Tārīkh al-Buṣrawī: șafahāt majhūlah min tārīkh Dimashq fì 
Apart from delineating a legal sphere of action for the ruler, siyāsa theorists and the sultans who sponsored them were launching a critique of procedural limits of the $\operatorname{shar}^{-} a$, which, as in the case of the Persian merchants narrated by al-Maqrīzī, could prove harmful to foreign merchants. Siyāsa courts enlarged their jurisdiction over various cases where the sharî $a$ "formalistic attitude to proof and evidence prevented the application of justice." 28 For instance, the $h \bar{a} j i b$ sat in judgment in divorce cases, because the $q \bar{a} d \bar{l}$ courts required four eyewitnesses to prove adultery. Siyāsa theorists criticized the qā $d \bar{l} s^{\prime}$ formalistic system of proof and, for instance, went so far as to legalize judicial torture, something considered illegitimate in the $\operatorname{shar}^{-} a$ and a point implicit in al-Maqrīzī's account: had the cheating merchants not been "punished" by the $h \bar{a} j i b$ - as explicitly recommended by Ibn Taymìyah-justice would never have been done. By claiming royal jurisdiction for mixed affairs, diplomats, sultans, and jurists were placing mixed cases in an area of legal practice where the major biases of traditional Islamic justice could be circumvented. Disciples of Ibn Taymiyah, such as Ibn Qayyim al-Jawziyah and Ibn Farhūn, rationalized court procedure by enhancing the importance of written and circumstantial evidence and by allowing the judge to rely on signs and indicators, not only on the word of witnesses. ${ }^{29}$ Ibn Qayyim (d. 1350) reformed his own school's views on the problem, and went so far as to claim that nothing in the Hanbali tradition prevented Jews, Christians, and Zoroastrians from being witnesses for mixed issues and, in cases of necessity, even in lawsuits concerning Muslims. $^{30}$

Venetian descriptions of siyāsa lawsuits offer a new perspective on these problems and on Mamluk legal attitudes towards non-Muslims. According to the treaties, siyāsa courts heard mixed cases, but how did they deal with proof and testimony provided by Franks? For travelling merchants, proving claims in the courtroom was fundamentally a matter of producing written evidence. To secure proof of their transactions, merchants had both Islamic and Western notaries at their disposal. But was the legal value of their deeds equal? Could Islamic courts accept Latin deeds? Conversely, could a Venetian notary acknowledge the trustworthiness and probity of an Islamic contract?

\footnotetext{
'Așr al-Mamālīk, min sanat 871 H li-ghāyat 904 H, Akram Ḥasan 'Ulabī, ed. (Damascus; Beirut: Dār al-Ma'mūn lil-Turāth, 1988), 119.

28 Rapoport, "Royal Justice," 80.

29 Baber Johansen, "Le jugement comme preuve. Preuve juridique et vérité religieuse dans le Droit Islamique Hanéfite," Studia Islamica 72 (1990); Johansen, "Signs as Evidence.” On Ibn Qayyim's attitude to written documents, see G. Bechor, God in the Courtroom: The Transformation of Courtroom Oath and Perjury between Islamic and Franco-Egyptian Law (Leiden: Brill, 2011), 347.

${ }^{30}$ Muhammad ibn Abī Bakr Ibn Qayyim al-Jawzìyah, al-Ṭuruq al-ḥukmīyah fì al-siyāsah al-shar'‘yah (Mecca: Dar al-'Alim, 1428 h), 470-82.
} 
THE FUNDAMENTAL PROBLEM OF PROOF AND EVIDENCE

If a framework to solve cross-communal conflict needed to be created, implementing the adoption of written contracts between Muslims and Franks was a first step. Apart from concentrating all jurisdictions in the hands of the siyāsa judges, fifteenth-century treaties included new provisions that Islamic notaries

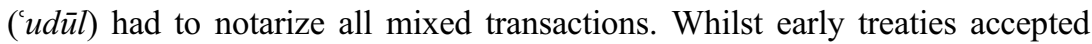
transactions either in or out of the customs (in dogana ... extra dogana), notarized by witnesses or not (cum testibus ... sine testibus), fifteenth-century 'amān treaties required that all mixed transactions should be notarized before Islamic 'udūl (yakūn shāhidayn 'ādilayn, takūn al-mu'ākida baynahum bil-'udūl, etc.) and, where they were available, sales were to be concluded at the customs house (yakūn dhalika fì dīwān). ${ }^{31}$

The word 'udūl signifies both a professional notary and any "righteous witness" in a given community. Ideally, any believer of good reputation could notarize provided he opened up shop at the market and was recognized by a local judge. ${ }^{32}$ In southern Europe, notaries were instead public officers appointed by the emperor or his delegates and they were required to pass an exam. According to Islamic classical jurisprudence, only trustworthy male Muslims were able to provide testimony, and some of these witnesses came to perform professional notarial services.

Yet not only formal differences existed between the Venetian clerks and their Islamic counterparts; Latin notaries were able to produce written documents endowed with legal value at court (empowered with public fides), while Islamic notarial deeds were not valid without the oral support of their authors. ${ }^{33}$ An Islamic document was not considered primary evidence until the witnesses and the notary who had drafted it appeared in the courtroom

31 Thomas and Predelli, Diplomatarium, I, 295 (article 22); R. Ruiz Orsatti, "Tratado de Paz entre Alfonso V de Aragon y el Sultan de Egipto, al-Malik al-Ashraf Barsbay," Al-Andalus 4 (1939), 343, 345, 361 (articles 11, 15, 26); John Wansbrough, “A Mamluk Commercial Treaty Concluded with the Republic of Florence, 894/1489," in S. M. Stern, ed., Documents from Islamic Chanceries (Oxford: Bruno Cassirer, 1965); Wansbrough, "Venice and Florence," 488 (article 4), 512 (article 5), 498: 35 (article 2).

32 Émile Tyan, Le notariat et le régime de la preuve par écrit dans la pratique du droit musulman (Harissa: Imp. St. Paul, 1945), 18-21.

33 For the use of deeds in similar contexts, see Robert I. Burns, Jews in the Notarial Culture: Latinate Wills in Mediterranean Spain, 1250-1350 (Berkeley: University of California Press, 1996), 32-51; Sally McKee, Uncommon Dominion: Venetian Crete and the Myth of Ethnic Purity (Philadelphia: University of Pennsylvania Press, 2000), 19-57; Daniel L. Smail, The Consumption of Justice: Emotions, Publicity, and Legal Culture in Marseille, 1264-1423 (Ithaca: Cornell University Press, 2003); and his "Notaries, Courts and the Legal Culture of Late Medieval Marseille," in Kathryn Reyerson and John V. Drendel, eds., Urban and Rural Communities in Medieval France, Provence and Languedoc, 1000-1500 (Leiden: Brill, 1998). 
and certified both the document and its content. ${ }^{34}$ The Franks involved in siyāsa lawsuits describe the 'udūl, therefore, as "witnesses who wrote."35

By the late Middle Ages, southern European cities witnessed the emergence of professional notaries. In the period under analysis, most Italian city states relied heavily on a new typology of notaries empowered with official authority, who drafted "public" notarial deeds and not just private acts, and it is generally agreed that the notarial act acquired juridical value at that time. The genuine character of a contract came to depend on the officer's signature rather than on the presence of witnesses. Notaries were incorporated into chanceries, courts of justice, and communal administrations such as the consulates in Alexandria and Damascus, where Venetian clerks became regular figures. They offered their services to the whole community, which, particularly in debt matters, could benefit from the validity of the notaries' acts in their own city's courts. ${ }^{36}$ As a result, deeds drawn up in Alexandria and Damascus found their way into trial proceedings held elsewhere. ${ }^{37}$ When they were brought before the $h \bar{a} j i b$, Frankish merchants procured themselves an official record to report back in Europe which is why they described their experiences with local justice to their notaries.

Yet the most striking divergences concern the probatory status of the written deed and the very different logics of its preservation. Venetian notaries kept a detailed copy of their deeds to be preserved in state archives; in contrast, ' $u d \bar{u} l$ records were valid only during the lifetime of their authors, and there was no need to preserve them afterwards. ${ }^{38}$ This might explain why Islamic notaries

34 Baber Johansen, "Formes de langage et fonctions publiques: Stereotypes, temoins et offices dans la preuve par l'ecrit en droit musulman," Arabica 44, 3 (1997): 333-76; Christian Muller, "Ecrire pour établir la preuve orale en Islam: Ia Pratique d'un tribunal à Jérusalem au XIVe siècle," in Akira Saito and Yusuke Nakamura, eds., Les outils de la pensée: Etude historique et comparative des textes (Paris: Editions MSH, 2010); Wakin, Function of Documents.

35 ASVe, CI, N, B. 222, Notary A. Vactaciis, f. 43r-v, undated (though surely drawn up between 5-9 Mar. 1401): Item soluit testibus saracenis a gabano qui scripserunt, f. 108r-v, 22 Dec. 1405: in testificatione testium saracenorum.

36 Among the profuse Italian scholarship on notaries are the monographs on Genoa and Venice included in the Studi storici sul notariato italiano series: Giorgio Costamagna, Il notaio a Genova tra prestigio e potere, (Milano: Giuffrè, 1995); Maria Pia Pedani, Veneta auctoritate notarius: storia del notariato veneziano, 1514-1797 (Milano: Giuffrè, 1996); together with several conference proceedings edited by Vito Piergiovanni, including Hinc publica fides: Il notaio e l'amministrazione della giustizia (Milan: A. Giuffrè, 2006). On the validity of notarial documents as juridical items "in court and outside," see Burns, Jews in the Notarial Culture, 38-43; Alessandro Pratesi, Genesi e forme del documento medievale (Roma: Jouvence, 1979), 47-55; and for Genoa and Venice, Attilio Bartoli, Notai: scrivere documenti nell'Italia medievale (Roma: Viella, 2006), 59-87, which provides an exhaustive bibliography.

37 Archivio di Stato di Genova, San Giorgio 590/1289, f. 106v. A Damascene deed dated 1447 by the Venetian clerk Andrea Michiel was produced as proof in a trial in Famagusta. For a trial in Genoa, see the de Negro trial, referenced below.

38 On preservation, see Christian Muller, "The Haram al-Šarīf Collection of Arabic Legal Documents in Jerusalem: A Mamlūk Court Archive?" al-Qantara 32, 2 (2011): 435-59. Venetian authorities put instead a great emphasis on the preservation of registers in state archives; see Marco. 
do not seem to have preserved notarial acts en minute, something Frankish traders found aberrant. A Catalan merchant living in Oran in 1475 had contracted debts with a Genoese partner by underwriting two Arabic notarial contracts. But he trespassed into the house of his Genoese creditor and stole the documents so that the latter could not prove the existence of the debts. As the Genoese merchant bitterly argued, "Muslim notaries do not preserve authentic copies of the deeds they draw up ... they do not keep registers. ${ }^{~}{ }^{39}$ Uncomfortable with this Weberian picture, historians of Islam feel the need to defend the sophistication of medieval Islamic written culture and the widespread use of documentation, and tend to justify the lack of extant archives. ${ }^{40}$ Yet the lower status of written evidence was not necessarily or specifically "Islamic" since it was most probably imported from imperial predecessors. Byzantine notaries followed identical logics in the production, use, and validation of documents as their Islamic successors. The problem with this black-and-white, essentialist picture of two opposed notarial systems is that it forgets that both were directly, if unequally, rooted in antiquity, and it presents the "Western" notariate as heir of classical Roman Law. Instead, public faith claimed by imperial notaries was a legal fiction construed in medieval times. Romans and Byzantines did not have public notaries. Rather, they had clerks (tabelliones) that drafted private deeds with no real public character. According to Justinian codes, copies were not kept and notaries were summoned to court to prove the authenticity of a given document. ${ }^{41}$

How, then, did merchants decide which of these two legal institutions to use? It may seem obvious that Latin clients chose Venetian notaries: here they found legal, linguistic, and personal affinities. Yet, as will be argued in the following pages, a strict confessional divide did not exist; Latin notaries coexisted with Muslim ones, and both offered their services to mixed clienteles. Clients sought the support of the ' $u d \bar{u} l$ to guarantee the validity of their transactions in local markets and courts, and they did so irrespective of their own religion. A Jew of Crete gave an Islamic power of attorney in 1400 to a

\footnotetext{
A. Bigaglia, Capitulare legum notariis publicis Venetiarum (Venice: Andrea Poleti, 1689), 16, 24 27; Joseph R. Wheeler, The Sestiere of San Polo: A Cross Section of Venetian Society in the Second Half of the Fifteenth Century, PhD thesis, University of Warwick, 1995, 12-14.

39 Archivio di Stato di Genova, Notai Antichi, 871, doc. 295: mauri non tenent autenticum instrumentorum per ipsos conpositorum; and again in doc. 296: notari barbari non tenent registrum instrumentorum per ipsos conpositorum.

40 Tamer el-Leithy, "Living Documents, Dying Archives: Towards a Historical Anthropology of Medieval Arabic Archives," al-Qantara 32, 2 (2011): 389-434; Muller, "Haram al-Šarīf Collection," 456-58, questions instead the existence of proper $q \bar{a} d \bar{l}$ archives in pre-Ottoman times.

41 Jean-Philippe Lévy, Autour de la preuve dans les droits de l'antiquité (Naples: Jovene, 1992), 155-75; Laurie Nussdorfer, Brokers of Public Trust: Notaries in Early Modern Rome (Baltimore: Johns Hopkins University Press, 2009), 9; Mark W. Steinhoff, Origins and Development of the Notariate at Ravenna (Sixth through Thirteenth Centuries), PhD thesis, New York University (Ann Arbor: University Microfilms International, 1976), 73-75.
} 
Rhodes consul, empowering the latter to rescue debts traceable in Latin deeds. As clients of the 'udūl, Franks procured locally produced evidence of their transactions, but in the last instance this was valid only in local courts, and only if supported by those Muslims who had been present at the transaction. Similarly, fifteenth-century Venetian notaries sold their services to merchants of various religious and ethnic backgrounds, particularly when recognition of their transactions was sought before Frankish associates and legal institutions.

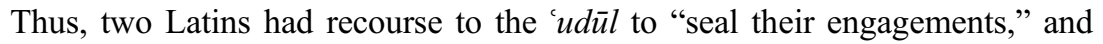
also, though more rarely, two Muslim parties could underwrite a Latin contract. $^{42}$

Grounded in very different juridical traditions, the approaches to the fundamental issue of evidence and proof by the two notaries differed. Yet, in practice they complemented each other, as the 'udūl backed their own acts at the local courts whilst Latin deeds were required for possible trials back in Europe, where they had probative value. The two institutions together produced evidentiary artifacts to legalize private transactions, to support arbitration panels and other private arrangements sealed before the parties arrived in court. At court, only professional witnessing by the ' $u d \bar{u} l$ was acceptable to the qua dīs. Siyāsa judges, instead, seem to have issued verdicts on the basis of not only notarial deeds but also correspondence, accounts, and other kinds of written evidence, and as we will see, they collaborated with Venetian notaries in the taking of oaths from Franks.

\section{MERCHANTS AND NOTARIES}

The earliest substantial collection of deeds comes from the notary Giovanni Campione, who sojourned in Alexandria for twenty-three months in 13611363. Of the 165 people mentioned in his notebook, only one identified himself as an Eastern Christian and one other is labeled as a Muslim. ${ }^{43}$ As Egypt and Syria became the center of networks dealing in the spice trade, the notaries' task became more complex. In the extant fourteenth-century casebooks, notarial deeds almost exclusively concern Latins. However, in the fifteenth century, not only local Muslims but characters from varied backgrounds found their way into the protocols. To make a clear distinction between the religious minorities under the umbrella of Western powers and those under Islam, the notaries enlarged their formulaic, largely fossilized

\footnotetext{
42 ASVe, CI, N, B. 222, Notary A. Vactaciis, f. 17r, 2 Mar. 1400: procuratore ... pro quadam carta moresca. Sometimes deeds were drawn up to deal with Muslim third-party associates: ASVe, CI, N, B. 83II, Notary C. Del Fiore, 2 May 1461; ASVe, CI, N, B. 148, Notary P. Pellacan, 7 Oct. 1444: una charta moresca mi rechiedete chio fazi a chonfirmatione de uno chompromesso fatto tra ser fra Antonio Mozzo e me; ASVe, Notarile Testamenti, B. 215, Notary S. Peccator, 14 Oct. 1448; ASVe, CI, N, B. 211, Notary N. Turiano, 21 May 1455.

${ }^{43}$ ASVe, CI, N, B. 36, Notary G. Campione, 27 Oct. 1362: christianus a centura; 28 Oct. 1362, 30 Oct. 1362: saraxino.
} 
Latin terminology. Hence, the Jews of Islam are sometimes named judeus ebraicus, an epithet distinguishing them from the Jews of Venice. ${ }^{44}$ On occasion, the notaries adapted their terminology to clearly identify Muslims (for instance, as Saracen moors) versus the more common Arabic-speaking Christians. ${ }^{45}$ Muslims could also be "foreign," like the Maghrebis, or vassals of Christian rulers such as the Iberian Muslims. In consequence, in their Latin jargon the notaries drafted people's jurisdictional location as best they could, as in the complex case of Abdella, judeus ebraicus magrabi de Tunisio, habitator in Damasco. ${ }^{46}$

The major challenge, though, was labeling the different kinds of Christians. Most often, Oriental Christians were indistinctly categorized as "Christians of the Girdle." However, the notary also had to deal with members of Oriental churches living in Cyprus or elsewhere in the former Byzantine territories, who to avoid confusion were labeled differently. The complexity of notarial taxonomies is particularly evident in deeds where Oriental Christians from Islamic lands engaged in business with their coreligionists from places such as Rhodes or Cyprus. ${ }^{47}$ In such circumstances, the notary's use of murky religious and ethnic categories conceals juridical situations that are difficult for us to reconstruct. Two clerks used the word fazolati to designate an Arabic-speaking Christian minority operating mainly from Cyprus. ${ }^{48}$ What the growing level of complexity reached by fifteenth-century notarial terminology suggests is that Venetian clerks were now operating at the intersection of two spheres of jurisdiction, which transcended any simplistic Christian-Muslim dichotomy. As Ibn Taymīyah points out in his Siyāsa Shar ìya, the matter was of crucial importance, because the Christians and Jews of Islam were charged only half the taxes of their coreligionists subject to Christian powers. Both the notaries and the Mamluk secretaries were now facing the legal problem of whose jurisdiction these Christians and Jews fell under. While Venetian notaries responded by adopting an increasingly complex terminology, an encyclopedia for the use of chancery staff discusses the different Christian sects in order to clarify which were led by Oriental patriarchs and were therefore subject to the sultan irrespective of where their members lived. ${ }^{49}$

\footnotetext{
${ }^{44}$ ASVe, CI, N, B. 230, Notary N. Venier, f. 13r, 3 Apr. 1419: cuidam Ellie, judeo ebraicho, illo tunc existenti in Damasco et ad presens habitatori dicte civitatis Nichosie.

${ }^{45}$ ASVe, CI, N, B. 230, Notary N. Venier, f. 9v, 18 Oct. 1418: aliquibus mercatoribus saracenis moris.

${ }^{46}$ ASVe, CI, N, B. 230, Notary N. Venier, f. 13r, 4 May 1419.

47 ASVe, CI, N, B. 222, Notary A. Vactaciis, f. 74v, 20 Oct. 1404; f. 183v, 29 July 1405; ASVe, CI, N, B. 211, Notary N. Turiano, f. 59v, 4 Oct. 1455.

48 ASVe, CI, N, B. 222, Notary A. Vactaciis, f. 80r, 3 Dec. 1404: Salem façolato habitatori nicosie presenti et intelligenti per Nessinum interpretem venetorum lingua Arabica; ASVe, CI, N, B. 230, Notary N. Venier, f. 19v, 29 May 1419: in su laqual nave I era haver de mori e fazolati per $i$ quali franchi ... ano habudo de grande strazo.

49 al-Khālidī, al-Maqșad al-rafì', f. 138-41; Ibn Taymīyah, al-Siyāsah al-shar'ìyah, 55-56.
} 
During the fifteenth century, Muslims and Christians of Islam became frequent clients of Venetian notaries. They often gave power of attorney to Franks, for matters ranging from the capture of a slave to the recovery of debts. ${ }^{50}$ Providing services to Mamluk subjects implied a de facto acceptance that the validity of notarial deeds was universal ("ubique terrarum"), at least in the territories under the theoretical jurisdiction of the Roman Empire, which included the Mediterranean Levant. ${ }^{51}$ Together with the very idea of public faith, this second legal fiction permitted notaries to present themselves as a universal institution to which any merchant could appeal. Moreover, by extending their services to individuals under Islamic jurisdiction, notaries were implicitly granting public faith to their legal documents. The notary often quoted documents in Arabic, generally referred to as "Moorish letters," but also in Hebrew, presented by clients as evidence of previous business relations. The Venetian clerks had books of account and customs records translated, and on occasion they made reference to private Arabic acts and contracts. ${ }^{52}$ Among these documents we can find Islamic notarial deeds drawn up by the ' $u d \bar{u} l$ and validated by witnesses. In a much disputed case, two Muslims were called to witness an agreement between a Florentine consul and a Venetian jeweler in Alexandria ("ad conficiendum saltem per duos testes mauros unam cartam morescam"). These "Moorish letters" were later used to solve disputes before Christian courts in Alexandria and Rhodes. ${ }^{53}$ Franks who went into partnerships with Muslims often employed Arabic contracts ("cartas, instrumenta et scripturas lingua Arabica scriptas"). ${ }^{54}$

Mediterranean historians have argued that, legally, relations were limited to the occasional validation of the other's probative artifacts. ${ }^{55}$ According to this narrow vision, Islamic-produced evidence was accepted by Franks only if compliant with Islamic rules of proof and the other way around. But the combined, mutually enforcing use of legal instruments provides us with legal relations that

50 ASVe, CI, N, B. 222, Notary A. Vactaciis, f. 41r, 25 Feb. 1401; f. 119v, 16 Aug. 1406; ASVe, CI, N, B. 22, Notary V. Bonfantin, 28 June 1419; ASVe, CI, N, B. 230, Notary N. Venier, f. 5v-6r, 18 May 1418; f. 6r-v, 16 May 1418; ASVe, CI, N, B. 148, Notary P. Pellacan, 9 Nov. 1444; ASVe, Notarile Testamenti, B. 215, Notary S. Peccator, 10 Oct. 1448; ASVe, CI, N, B. 83II, Notary C. Del Fiore, f. 15v, 14 June 1426; f. 24r, 30 May 1426; ASVe, CI, N, B. 211, Notary N. Turiano, f. 38,8 Feb. 1435.

51 Gabriella Airaldi, Studi e documenti su Genova e l'oltremare (Genova: Università di Genova, 1974), 209; James M. Murray, Notarial Instruments in Flanders between 1280 and 1452 (Bruxelles, Académie Royale, 1995), 11.

52 ASVe, CI, N, B. 222, Notary A. Vactaciis, f. 17r, 2 Mar. 1400, mentions an Arabic contract drawn in Cyprus; ASVe, CI, N, B. 83II, Notary C. Del Fiore, 2 May 1461: vigore certe carte arabice, se constituerit plezium. As for contracts in Hebrew: vigore unius scripti anotati in ydiomate ebreo, ASVe, CI, N, B. 211, Notary N. Turiano, f. 66r, 26 July 1428.

53 ASVe, CI, N, B. 148, Notary P. Pellacan, 7 Oct. 1444; ASVe, CI, N, B. 211, Notary N. Turiano, f. 38,8 Feb. 1435, an Arabic contract is produced as evidence to be used before Rhodian courts.

${ }_{55}^{5}$ ASVe, CI, N, B. 211, Notary N. Turiano, f. 46v, 11 Sept. 1455.

55 Valérian, "Le recours à l'écrit," 68. 
go beyond a simple Islamic/Frankish polarity to a truly multifaceted situation. As Kate Fleet has shown for judicial cooperation in pre-Ottoman Turkey, Frankish and Muslim officials sat in justice and delivered verdicts together. ${ }^{56}$

Depositions and sworn testimonies by Muslims recur frequently in the ledgers. Notaries accepted statements in Arabic and Turkish, validated either by official dragomans (interpreters) or by simple merchants. Hence, someone might speak "in a translated voice" (dixit et testificatum fuit suo sacramento iurando per vocem turcimatam) or "understand" through another person. ${ }^{57}$ In 1404, a disagreement had arisen about a shipping contract underwritten by two Cypriots. The contract had been drawn up in Arabic by the Arab-speaking Cypriot merchant, Salem. He took part in an attempt to arbitrate the dispute through the mediation of a Venetian dragoman. The arbitration, accordingly, was notarized on the basis of the linguistic mediation and the validity of the Arabic document. Beyond this cultural sophistication delivered by notarization, mutual recognition required a certain legal accommodation, particularly with witnesses. The notary was compelled to accept oaths and testimonies from Muslim courtiers and dragomans even when, embarrassingly, they were Christian renegades. Their condition of apostates is generally made explicit (olim christianus fidelis ad presens saracenus). Though authorities recommended that oaths by non-Christians should be sworn on "their old texts," when renegades were called to swear on "the scriptures" we are not informed which scriptures these were. ${ }^{58}$

Although recourse to Venetian notaries became widespread in the fifteenth century, could everyone be a witness? Siyāsa thinkers such as Ibn Qayyim and the Venetian colonial authorities were equally concerned about this issue. Gathering testimony from unbelievers represented a challenge to the accepted norms since, either at court or before the notary, witnessing implied being an actor in the legal system, not just a passive subject. Again, a comparative description of how norms were put into practice suggests that common attitudes were adopted in spite of doctrinal differences. Apart from the Hanafîs, Islamic jurists denied the ability of non-Muslims to guarantee the will or claims of others as witnesses. As a result, the rare Islamic notarial acts known where non-Muslim witnesses are involved regard other non-Muslims. ${ }^{59}$ In contrast to shari ${ }^{-} a$, nothing in

\footnotetext{
${ }^{56}$ Kate Fleet, "Turkish-Latin Diplomatic Relations in the Fourteenth Century: The Case of the Consul," Oriente Moderno 22 (83), 3 (2003): 605-11.

${ }^{57}$ Examples are two sworn testimonies by Muslims: ASVe, CI, N, B. 211, Notary N. Turiano, f. 30v, 4 Mar. 1435; and again f. 48r, 27 Apr. 1435: per vocem turcimatam cuidam vocati Acmar saraceni.

${ }^{58}$ ASVe, CI, N, B. 222, Notary A. Vactaciis, f. 80r, 3 Dec. 1404; ASVe, CI, N, B. 211, Notary N. Turiano, f. 58v-59r, 9 Aug. 1435; f. 61r, 19 Aug. 1435; f. 30r, 8 Dec. 1434; ASVe, Notai di Venezia, 14832, Notary I. Dalla Torre, f. 2 (n. 2), mentions a Genoese dragoman, "olim cristiano," 31 May 1412.

${ }_{59}$ Yusuf Ragib, Actes de vente d'esclaves et d'animaux d'Egypte médiévale, vol. 2 (Le Caire: Institut Français d'Archéologie Orientale, 2006), 107.
} 
Venetian law prevented non-Christians from being witnesses to deeds, though in practice this happened only in contracts where their coreligionists were involved. In Alexandria and Damascus, notaries stuck uniformly to this practice. ${ }^{60}$ Similarly, specialists in Genoese history underline that, even in the absence of an explicit prohibition, in practice the Jews of Genoa appeared as witnesses only to deeds underwritten by other Jews. By shifting the focus from normative differences to practice, my intention is not to flatten out $\operatorname{shari~}^{-} a$ and reduce its differences with Western law, but rather to stress that, even in matters where Latins and Muslims relied on different legal doctrines, striking coincidences emerge in the practical ways that norms were implemented. ${ }^{61}$ Both legal systems dealt with the judicial oaths of minorities in a very similar way. For Venetian legal practice, the taking of judicial oaths by nonChristians was a familiar matter. In Venetian Crete, a special procedure had been established in 1340 to validate pledges pronounced by Jews. As infideles, they could not swear by the cross, so members of the Jewish community were subjected to a special oath-taking procedure that required their presence at the synagogue. In the same fashion, when the Inquisition started to gather depositions from Venetian Jews, they were allowed to swear to the truth of their testimony with a Jewish formula, a solution coinciding with that found in the

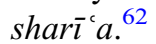

What these apparent surprising coincidences really hide is the incorporation by Christian powers of Islamic concepts of difference, like the doctrine by Mālikītes, Shāfi'îtes, and some Hanbalīs recommending that Jews and Christians take their oaths in their houses of prayer. ${ }^{63}$ This late medieval transfer was not peculiar to Venice but found its way into legal codes of other expanding Christian powers, such as Castile. ${ }^{64}$ Yet again these biases against minorities were not specifically Islamic but reformulations of preexisting late Roman

${ }^{60}$ Non-Christian witnesses appear invariably in deeds related to other Non-Christians: ASVe, CI, N, B. 22, Notary V. Bonfantin, 17 Jan. 1393; 28 June 1419; ASVe, Notarile Testamenti, B. 215, Notary S. Peccator, 2 May 1448; 5 Oct. 1448; 14 Oct. 1448; ASVe, CI, N, B. 211, Notary N. Turiano, f. 6v, 21 May 1455.

${ }^{61}$ On non-Muslim witnesses, see Antoine Fattal, Le statut légal des non-musulmans en pays d'Islam (Beyrouth: Impr. Catholique, 1958), 361-64; Emon, Religious Pluralism, 136-41; Ragib, Actes de vente, 105-15. For minority witnessing in Genoa's colonies, see Philip P. Argenti, The Religious Minorities of Chios: Jews and Roman Catholics (Cambridge: Cambridge University Press, 1970), 100-46.

62 Elisabeth Santschi, "Contribution à l'étude de la communauté juive en Crète vénitienne au XIVe siècle, d'après des sources administratives et juridiques," Studi Veneziani XV (1973), 177211, 207-8; R. C. Head, "Religious Boundaries and the Inquisition in Venice: Trials of Jews and Judaizers, 1548-1580,” Journal of Medieval and Renaissance Studies 20, 2 (1990): 175-201.

63 Bechor, God in the Courtroom, 122-27.

64 Belen Vicens, "Swearing by God: Muslim Oath-Taking in Late Medieval and Early Modern Christian Iberia," Medieval Encounters 20 (2014): 117-51; Mélanie Jecker, “Jurer selon sa religion: La figure de l'autre dans le droit médiéval castillan," in Lucien Faggion, Christophe Regina, and Bernard Ribemont, eds., La culture judiciaire: Discours, représentations et usages de la justice du Moyen Age à nos jours (Dijon: Presses universitaires de Dijon, 2014). 
(Christian) legal concepts. ${ }^{65}$ The prejudice toward female witnesses perhaps better suggests the continuous borrowing of solutions to fundamental legal questions. Qur'an 2: 282 prescribes the need for two female witnesses in place of one man, which is often counted among the major legal biases of $\operatorname{shari~}^{-} a$ and generally upheld in legal practice. When the Great Council of Venice in 1475 reinforced the role of witnesses for last wills and testaments, two women were required to take the place of one man. ${ }^{66}$

\section{Conflict Resolution in and out of the Courtroom}

Thinking about legal pluralism in the Mediterranean as the ability to switch between Islamic and foreign courts, where the former was just a second best, oversimplifies the nature of justice. Many mixed conflicts were solved out of court, siyāsa trials being the keystone of the judicial system. Arbitral, consular, and Islamic courts enforced each other and a common notarial culture was involved at all levels. Notaries provided evidentiary support to settle and prevent disputes and thus helped breach the fundamental limitations of consular justice. Consuls had no jurisdiction over Franks from outside their own nation, or over the sultan's subjects. When Muslims failed "to honor their agreements," the Venetian consular court, "not having power over them," had no choice but to boycott the merchants in question so that no member of the consulate could engage in business with them. ${ }^{67}$ Although, on occasion, foreigners voluntarily submitted to the jurisdiction of other consuls, an extant register of the Venetian consular court of Alexandria suggests that consuls almost exclusively settled internal disputes. ${ }^{68}$ The preferred extrajudicial way to solve cross-national conflict was arbitration. Consuls, but also trustworthy merchants, formed arbitration panels. Though notarized arbitration emerges mainly for issues among Latins, it should be noted that, to issue their verdicts arbiters inevitably relied on the customs administration. Lawsuits turned on evidence produced by the Christian scribes (scribani doane, scribas christianos a centura dicte doane) and the Muslim 'udul (testes saracenorum) attached to the customs authorities and translated by dragomans, mostly Jews. $^{69}$

${ }^{65}$ Fattal, Le statut légal, 361-64.

${ }^{66}$ Bigaglia, Capitulare, 28-29.

67 ASVe, CI, N, B. 229, Notary L. de Valle, Verbali del consiglio, 11 May 1402: cum mulcti mercatori saraceni et aliis forensis faciant mercata cum mercatoribus nostris ... sed quem super ipsos non possit dare ordo necesse est super mercatores nostros providere.

${ }_{68}$ ASVe, CI, N, B. 229, Notary L. de Valle, Verbali del consiglio, Oct. 1401-Oct. 1403; Christ, Trading Conflicts, 72.

${ }^{69}$ ASVe, CI, N, B. 222, Notary A. Vactaciis, f. 108r-v, 22 Dec. 1405; ASVe, CI, N, B. 211, Notary N. Turiano, f. 32v, 34v, 11 Mar. 1435. Some treaties allowed mixed arbitration, if on a voluntary basis: Orsatti, "Tratado de Paz," 343, 361. Fleet, "Turkish-Latin Diplomatic Relations," 609-10, mentions episodes of mixed arbitration. A mixed suit (vertenza) between a Dragoman and a Venetian is in ASVe, CI, N, B.122, int.25, f. 10v-11v, 10 Apr. 1436. 
All too often, historians have attributed the success of arbitration to a desire to avoid "formal" justice. The preference for arbitration over litigation has emerged in recent scholarship as the keystone for solving social conflict in late medieval cities. Genoa and its overseas cosmopolitan colonies witnessed the emergence of mixed arbitration courts similar to those of Alexandria and Damascus. ${ }^{70}$ Yet the capacity of notarized arbitration to enforce the law in mixed contexts presented its own limitations. Arbitration implied agreement by both parties over the election of judges, but there was often disagreement over the nation and the number of arbitrators. A Catalan refused the decision taken by only two arbiters on the basis that neither of them was Catalan. ${ }^{71}$ Acrimony pushed the parties to enlarge the panel up to even eight members. In Alexandria, in contentious cases it became necessary to draw lots for the panel. Moreover, arbitration was limited to cases in which both parties voluntarily submitted to the court's decision. Needless to say, decisions by the arbitrators were not always respected by the losing party. ${ }^{72}$

It may be tempting to view recourse to Islamic courts as being motivated by a need for coercion, and to see siyāsa tribunals only as courts of appeal when arbitration failed. ${ }^{73}$ This would be a rigid simplification, since the parties were not interested in obtaining a satisfactory decision by means that could be considered prejudicial to their reputation. The behavior of a Muslim from Mecca, al-Sharîf Hasan, may serve as an example of how solutions stemming from notarial culture intermingled with the formal authority of Islamic courts. In 1441, two Catalan merchants committed to providing certain goods to Hasan, who intended to send them back to Mecca with the seasonal caravan. A Florentine merchant backed the operation as a third-party guarantor by underwriting an Arabic document. The Catalans never honored their agreements, the caravans departed for Mecca, and the Florentine was held responsible for the loss. Even though his responsibility as guarantor was clear to all and sundry in the city,

70 Thomas Kuehn, "Law and Arbitration in Renaissance Florence," in Law, Family \& Women: Toward a Legal Anthropology of Renaissance Italy (Chicago: University of Chicago Press, 1994); Shona K. Wray, "Instruments of Concord: Making Peace and Settling Disputes through a Notary in the City and Contado of Late Medieval Bologna," Journal of Social History 42, 3 (2009): 733-60. For Genoa and its Greek colonies, see Steven Epstein, Genoa \& the Genoese, 958-1528 (Chapel Hill: University of North Carolina Press, 1996), 64-65; Brian N. Becker, Life and Local Administration in Fifteenth-Century Genoese Chios, PhD thesis, Western Michigan University (ProQuest Dissertations and Theses, 2010), 214-15.

${ }_{71}$ ASVe, Notai di Venezia, 14832, Notary I. Dalla Torre, f. 3v, 17 Sept. 1412: vos non habui nec habeo per meos judices, qui debetis esse quatuor vel quinque ... et nichil contra nationes catelanorum non habetis ad iudicandum.

${ }^{72}$ For an eight-member panel drawn by lots, see ASVe, CI, N, B. 148, Notary P. Pellacan, 29 Sept. 1444. The parties added supplementary members to judge again in case of disagreement with the final decision: ASVe, CI, N, B. 222, Notary A. Vactaciis, f. 93r, 2 Sept. 1405. A consul compelled a reluctant defendant to accept arbitration, yet he was at liberty to choose the board: ASVe, CI, N, B. 211, Notary N. Turiano, f. 21r-23r, 16 Aug. 1455: veniatis ad arbitrium mercatorum cuiuscumque nationis quam velitis.

${ }^{73}$ This seems to have been the case in Geniza times; Goldberg, Trade and Institutions, 161. 
both parties agreed to submit the question to a Latin arbitration court. As a Muslim, Hasan had no need to come before such a tribunal, yet this choice served his interest in establishing himself in the public eye as someone who would not bring his Frankish partners to the Islamic courts. Given the Florentine's discontent with the verdict, the case was eventually brought "as usual" before a royal court held by the emir, who had the parties heard again and convicted the Florentine for a second time. Even in that case the Muslim merchant asked the emir to consult Frankish merchants about the issue. The Franks gathered in an inn and again had both parties heard, eventually pronouncing unanimiter a condemnatory verdict for the third time. The episode, which left a long trail of notarized statements and depositions, and where Islamic and Latin documents were used for evidentiary purposes, shows the complexities of administering interfaith justice and the complementary role of the legal devices involved. ${ }^{74}$ Going beyond mere coexistence, courts proved to be complementary in enforcing verdicts, as did both notariates in proving claims by the litigants. In 1444, an eight-member panel dealing with a quarrel allowed the winning party to turn to Islamic justice to enforce the panel's decision. ${ }^{75} \mathrm{On}$ at least two occasions, Mamluk officials handed a dispute over to the Venetian consuls. $^{76}$

MERCHANTS AT THE ISLAMIC COURTS: A LENDER OF LAST RESORT?

The consolidation of siyāsa shar'iya as a doctrinal legitimation for state authority, with its emphasis on utility and public good, set the conceptual grounds for transferring jurisdiction over Frankish merchants to the royal courts. Yet siyāsa is not to be understood solely as a normative imposition by the sultans; rather, it was consolidated as a suitable answer for mixed conflict. In this regard, it is interesting to note two things: First, siyāsa justice did not totally override the jurisdiction of the $q \bar{a} d \underline{l}$ courts. Muslim plaintiffs continued to bring Franks before the qāạis. This happened in relatively simple cases, in which the judge could call upon the testimony of the 'udūl. As plaintiffs, Franks only had recourse to the siyāsa tribunals. By the mid-fifteenth century, Latins mentioned in their contracts the royal courts as the local forum where any suits should be filed. ${ }^{77}$ Second, in spite of the clauses defining the competent courts in fifteenth-century treaties, siyāsa did not operate in cross-communal

\footnotetext{
74 The arbiters inspected the Arabic notarized contract: visa quadam carta more saracenorum, and the consulate registers: carta testificationis ... in libro Actium; ASVe, CI, N, B. 211, Notary N. Turiano, f. 42r-45v, 9-10 Sept. 1455.

75 ASVe, CI, N, B. 148, Notary P. Pellacan, 29 Sept. 1444: pro qua executione per partem victorem contra partem tunc victam possit licite peti et implorari ac obtineri iuditium subsidium et favores maurorum et alterius cuiuscumque generationis.

76 ASVe, CI, N, B. 222, Notary A. Vactaciis, f. 108r-v, 22 Dec. 1405: electo et constituto iudice per magistratus Alexandrie. See also the de Negro case discussed below.

77 ASVe, CI, N, B. 83II, Notary C. Del Fiore, f. 15v, 5 Nov. 1463: comparendum in quocumque iuditio et offitio et coram quibuscumque dominis saracenis ... et universis officialibus mauris.
} 
cases alone, but frequently intervened in disputes among the Franks themselves. Perhaps most important, siyāsa justice beat the unwritten rule that conflicts among Latins should be solved without recurring to the Muslim authorities. The frequency with which these injunctions were disobeyed suggests, instead, that siyâsa was a suitable solution for Latins.

\section{Mixed Cases at the Qāḍ̄ Court}

As we have seen, treaties signed after 1360 took mixed cases out of the hands of the $q \bar{a} d \bar{l} s .^{78}$ However, daily commercial practice could deviate from the letter of the treaties and the doctrine of jurisprudents, as Muslim claimants still brought mixed cases before the $q \bar{a} \underline{d} \bar{l} s$. Two Damascene lawsuits, dated to 1418 and 1434, turned on testimony provided by the courtier (simsār) about exchanges between Muslims and Franks. The simsār acted here as a professional witness, almost certainly registered as one of the trustworthy ' $\bar{u} d \bar{u} l$ at the court, and the cases were easily solved in favor of the Muslim plaintiffs. The simsār certified before the $q \bar{a} d \bar{l}$ the transactions previously concluded in his presence. In compliance with the procedural norms of the $\operatorname{shari~}^{c} a$, he did this by reading the written records he had previously drawn up. According to the new agreements, all mixed transactions had to be notarized, and so a specialized courtier was needed (publicum sansarium inter mercatores cristianos et saracenos). This peculiar simsār-dragoman acted as a notary, and therefore appeared in court as a professional witness on behalf of the Franks. This institution illustrates perfectly how interaction generated solutions to some fundamental biases of $\operatorname{sharl}^{-} a$, such as that of minority witnessing, without challenging the accepted norms followed by the $q \bar{a} d \bar{l} \bar{s}$. In both cases, the simsàr was brought again to testify "more saracenorum" in a separate juridical act, this time before the Venetian notary. In both cases, the defendants were agents of third-party investors and, most probably, had the testimony from the simsār notarized as a disclaimer in future lawsuits. ${ }^{79}$ Finally, one single document makes reference to two Frankish litigants appealing to the $q \bar{a} d \bar{l}$ court. The parties "had recourse to Christian justice" to settle their dispute in Damascus, then turned to the local $q \bar{a} d \bar{l}$, and eventually to arbitration. The parties litigated over many years and eventually settled the dispute in Cyprus. ${ }^{80}$ Particularly the first two of these trials suggests that Muslim

${ }^{78}$ For the 1271 treaty, see Holt, Early Mamluk Diplomacy, 145-46. The first explicit mention of the siyassah courts as competent for mixed trials can be found in the 1368 draft treaty with Cyprus: René De Mas Latrie, Histoire de l'île de Chypre sous le règne des princes de la maison de Lusignan, 3 vols. (Paris: Imprimerie impériale, 1852-1861), 2, 293.

79 ASVe, CI, N, B. 230, Notary N. Venier, 12 Oct. 1418; ASVe, CI, N, B. 222, Notary A. Vactaciis, f. 4r-v, 2 Sept. 1435.

${ }^{80}$ ASVe, CI, N, B. 222, Notary A. Vactaciis, f. 5v-6r, 8 Jan. 1436: tam coram iudicio cristiano videlicet coram domino consule veneciis ... quam coram domino er Cadi [sic] ipsius civitatis damasci certas lites habuerint et coram etiam quibusdam arbitris et arbitratoribus. A Venetian 
claimants preferred to address their legal claims to the $q \bar{a} d \bar{c} s$, particularly when they could rely on evidence produced in due Islamic form. However, siyāsa judges heard more complex cases requiring the use of circumstantial evidence, like written Latin deeds, or documents not supported by certified witnesses.

\section{Mixed Cases before Siyāsa Courts}

In light of accusations by learned men that the royal courts were merely arbitrary and contrary to the spirit of $\operatorname{shari~}^{\bar{c}} a$, various scholars have seen the hājibs as usurpers of the judicial functions of the $q \bar{a} d \bar{\imath} \bar{s} .{ }^{81}$ It is doubtful, however, that by transferring mixed cases to the haj jibs the Mamluks were seeking to promote an arbitrary alternative to the $\operatorname{sharl}^{-} a$. Venetian descriptions suggest the adoption of slight differences in procedure, together with more flexible methods of proof and investigation. But when compared to the issues brought before the $q \bar{a} d \bar{l} \bar{s}$, the fundamental difference regards the nature of the cases heard and the kind of evidence produced by the litigants. To the extent that they can be reconstructed through Venetian eyes, the commercial suits heard by siyāsa judges were of great complexity, often involving forms of evidence and testimony that were difficult to contain within the formalist requirements of the $q \bar{a} d \bar{l} \bar{s}$. Yet the barely dozen trials reported suggest that sometimes, siyassa judges did their best to comply, at least externally, with the procedural traditions of the $\operatorname{shari~}^{\complement} a{ }^{82}$

In one case, Muslim merchants appealed to the hājib of Damascus to enact reprisals upon Catalan merchants after a Catalan pirate had attacked a ship and seized merchandise belonging to both Muslims and Arab-speaking Christians. The hạjib started a trial that cannot be described as merely arbitrary, given that it relied upon the main forms of traditional procedure. As the Catalans were operating mainly through intermediaries, the hăjib focused on whether the merchandise could be considered Catalan and could therefore be seized. Needless to say, the Venetians and other Franks who were apparently handling Catalan goods did their best to embroil the judge in a complicated web of transactions. The $h \bar{a} j i b$, showing ample executive powers outside the court, had an intermediary in Beirut brought to Damascus to testify. After circumstantial evidence had been given, the hăjib used coercion to gain a confession. As the merchants did not provide a satisfactory explanation, the hăjib had everyone sent to jail until they produced a statement accusing other

was sentenced by the $q \bar{a} d \bar{\imath}$ Heanbalī of Damascus: ASVe, CI, N, B. 83II, Notary C. Del Fiore, 25 Oct. 1463.

${ }^{81}$ Rapoport, "Royal Justice," 73-80; Irwin, "Privatization," 64-65; Nielsen, Secular Justice, 105.

${ }_{82}$ For the greater liberty of royal courts to examine documentary evidence, see Nielsen, Secular Justice, 25-28. 
merchants. ${ }^{83}$ However, the way this new evidence was produced suggests a different approach to procedure by the häjib: the imprisoned merchants took an oath by swearing on the Gospels held by the Venetian notary-priest. The oath, taken outside the court and presumably handed in written form to the $h \bar{a} j i b$, was doubtless accepted by the court, since it succeeded in changing the situation of the defendants. Similarly, the interaction between the siyassa courts and the Venetian notary did not end with pronouncement by the judges in mixed cases. To enforce the court's decisions, Muslim litigants or the $h \bar{a} j i b$ himself went before the Latin clerk to publicize the decisions made in the courtroom. For instance, one Muhammad Ibn Musa notarized a receipt for the money his Frankish opponent was sentenced to pay. ${ }^{84}$

Complex rules of procedure were also followed in a mixed suit brought to the emir of Alexandria by two Muslims in 1401. A ship under a Genoese flag had just docked in the port of Alexandria loaded with Frankish merchants and their cargoes. Unexpectedly, these two Mamluk subjects claimed to be the owners of most of the ship's freight and demanded the wages be paid by the merchants on board. ${ }^{85}$ A judicial panel that included the emir and two qā $\bar{d} \bar{i} s$ conducted the lawsuit that followed - a format known in other forms of royal justice as the mazālim. The defendant, a Dalmatian merchant, advanced written evidence (the original freight contract notarized in Senj). He appeared in court and paid for the services of both a translator and an unspecified "attorney" (machademus, Arabic muqaddam). The Mamluk judicial machinery involved other actors; the Muslim claimants did not have immediate recourse to royal justice, but first had judicial officers sent to the defendant for several days (mittentis in zimis per plures dies). One of the major accusations against siyāsa - the judges' habit of selling verdicts for money-is mentioned in this trial. According to the Franks' account, he bribed one of the $q \bar{a} d \bar{l} \bar{s} s$ in exchange for pronouncing a mild sentence. ${ }^{86}$

\section{Siyāsa among Franks}

As stated earlier, the expanding role of siyāsa as a commercial jurisdiction soon overstepped the spirit of the treaties; royal courts took to hearing cases where both parties were Franks, rather than cross-communal cases involving Mamluk subjects and protected merchants. Siyāsa trials were frequent in Damascus, perhaps because consular institutions were less developed than in Alexandria.

\footnotetext{
83 ASVe, CI, N, B. 230, Notary N. Venier, f. 15r-16r, 18 May 1419: dimandandole mori alazebo chostoro abia de le robe de catellani; Nielsen, Secular Justice, 24.

${ }^{84}$ ASVe, CI, N, B. 83II, Notary C. Del Fiore, f. 24r, 31 May 1426; f. 15v, 14 June 1426: Mahomet ebne Muse morus ... recepisse per sententiam Admirati Alexandrie.

85 ASVe, CI, N, B. 222, Notary A. Vactaciis, f. 38v-39r, 18 Jan. 1401: asserunt se esse parcionabiles dicte coche ferazium pro medietate et melechi pro 1 tertium [sic].

${ }^{86}$ ASVe, CI, N, B. 222, Notary A. Vactaciis, f. 38v-39r, 18 Jan. 1401; f. 43r-v, undated (ca. 5-9 Mar. 1401).
} 
The first mention of such a trial dates back to 1397. The Florentine Andrea di Sinibaldo and the Venetian Bartolomeo Lombardo had set up a partnership in Damascus. Bartolomeo died owing money to his partner, but the family in Venice rejected the Florentine's claims. Pressed by his Arab creditors he brought the issue to the häjib who forced reprisals on the Venetian merchant community. $^{87}$

Appealing to the siyāsa courts impinged on unwritten customs regarding dispute resolution among Franks. Many complaints by defendants mention a tacit agreement not to apply to local justice for disputes among Franks, most particularly when the two parties belonged to the same nation. Siyāsa, however, undermined this agreement. Siyāsa courts intervened so frequently that, as the Franks themselves admitted, they became the only possible solution for disputes between subjects of different consulates. This was the case for a merchant from Montpellier compelled by the Genoese consul to pay some taxes. Genoa was temporarily under French protection, and this argument was used by the Genoese consul to present himself as a representative of the French king. The French merchant protested that the consul had applied to the häjib, "who holds the justice of the sultan in Alexandria." He should instead have advanced his claims before the French representative, as, he argued, "my consul has power over those on his funduk ... and knows better the facts between Frank and Frank than the justice of the Moors does." The Genoese consul attempted to "prove before the hajjib" that the Frenchman was handling Genoese goods and that he had gone into partnership with Genoese merchants, something the consul could hardly do without the help of Latin records and witnesses. ${ }^{88}$

By the same token, in October 1460 a Venetian in Damascus appeared before the Muslim authorities accusing a fellow national of several misdeeds, including silk smuggling and illegally trading slaves. The defendant denied the charges and accused the plaintiff of forging evidence, but his main argument relied on the fact that "it is against our laws and customs and against the consul's duties to bring our differences before the Muslim authorities, between Franks and particularly between Venetians." He reserved the right to protest to the consul for having tolerated this anomaly and apologized "before God and the world and before every merchant present here, that not by my doing will litigation before the Muslims take place, but because of you and your commissioners, violating our laws and our authorities'

${ }^{87}$ ASVe, Senato, Deliberazioni, Misti, 44, f. 56r, n.d.

${ }^{88}$ ASVe, CI, N, B. 222, Notary A. Vactaciis, f. 101r-v, 8 Dec. 1405: davant la jegp que ten la justiçia dels moros ... senyos de consols e franch que al present son en alexandria los cals coneixeran mells lo fach de franch a franch que non fara la justiçia dels moros; f. 107v, 14 Dec. 1405: davant la jegp dalesandria local ten en lo dit loch la iustiçia per lo soldan. 
dispositions." However theatrical the merchants might have been, their prejudices against Islamic justice sound genuine. ${ }^{89}$

In 1403, two powerful consulates in Alexandria, those of Venice and Genoa, engaged in a dispute concerning not a single individual but a larger group of merchants. The Genoese consul refused to elect an arbitration panel and instead applied to the justice of the emir. The Venetian consul complained, such a practice being considered "against all justice and equity." The Genoese consul reversed the argument, stating that the emir and governor "has always been and is the arbitrator and judge between the different Frankish nations, and his decisions and his will cannot be disobeyed." ${ }^{90}$ The losing parties complained that being judged by the emirs was "against the law and against justice," but it was their fellow countrymen who initiated these trials. ${ }^{91}$

Royal justice was also called upon to intervene in complex financial matters. One of these trials revolved around the close examination of written evidence and accounts. The trial was initiated by the Genoese consul, who, in the process of dealing with the consulate's finances, clashed with a merchant, Nicola de Negro, over some debts. To twist de Negro's arm, the consul brought him before the emir of Alexandria accusing him, in addition, of defrauding the sultan's treasury. He first publicly accused de Negro before the customs officers, then the case was brought to the emir, in whose house the session took place. The strategy consisted in proving the defendant's guilt on the basis of account books, something not technically possible at the $q \bar{a} d \bar{l} \bar{l}$ courts, who would never have taken into consideration written evidence without the support of righteous witnesses. The defendant, in turn, presented official correspondence from the Genoese authorities exempting him from these debts. According to the narrative by de Negro, the emir found the consul's claims exaggerated and "not in accordance with the law." However, the emir declined to take a decision and handed the case, surprisingly enough, to the Venetian consular court. As a subject of Genoa, de Negro had no need to come before a Venetian tribunal. Therefore, he voluntarily submitted to the judgment of the Venetians, though "only de iure," and the subsequent trial took place before an arbitration court, whose decision was not accepted as binding. ${ }^{92}$

${ }^{89}$ ASVe, CI, N, B. 83II, Notary C. Del Fiore, 21 Oct. 1460: et cum sie chelsia contra leze et consuetudine nostre et contra la commission del consolo a metter davanti segnorie de mori tal gare et defferentie tra francho e francho e maxime tra venezian e venezian.

90 ASVe, CI, N, B. 229, Notary L. de Valle, 10 Mar. 1403: et nec nos domino consul Ianuensis cum omnibus nostris mercatoribus contra quantibus equitatis et iustitiam mihi veneritis coram iuditio moresco ... contra iuditium dicti armiragii de quacumque re sit vel contingerit inter nos et vos dicere non possumus nec ultra voluntatis ipsius armiragii facere non possumus.

${ }^{91}$ As in a trial involving litigants from Gaeta, ASVe, CI, N, B. 211, Notary N. Turiano, f. 8v-9v, 1 Sept. 1434: contra ius et justitiam ... secundum mores et consuetudines et legem saracenorum et non secundum ... mores christianorum.

92 Archivio di Stato di Genova, Governo, Archivio Segreto, Materie politiche, f. 18B-2737B, n. 72: offerendosse voler provar questo cum li libri de la massaria, 15 Jan. 1493. 
A last instance of procedural cooperation between the several devices involved comes from a deed dated 12 February 1418. The evidence I have presented so far has concerned justice administered by the $q \bar{a} d \bar{l} \bar{s} s, h \bar{a} j i b s$, and emirs, referring to trials which occurred at different times and places. In contrast, this Venetian notarial deed was drawn up during one of these siyāsa sessions in Damascus. The deed is dated "Damasci in domo residentie prefati magnifici domini Azebi prope banchum juris"; that is, at the hajjib's house, and it mentions the platform (dikkah) from which the Mamluk officials gave their verdicts. A siy $\bar{a} s a$ trial has just finished, and the $h \bar{a} j i b$ has made a decision. A Genoese and a Venetian merchant have applied to the hajjib and he has found their claims to be just (decernens atque considerans petitione ipsorum ... justas fore). In consequence, the hājib has seized some merchandise held by another Genoese merchant. Circumstantial evidence is mentioned in the form of correspondence setting out the ownership of the merchandise. As a result, the defendant has been asked to take an oath about the veracity of the testimony by the plaintiffs and supported by the correspondence. The hajjib sticks here to traditional $\operatorname{shari~}^{-} a$ procedure, which allowed anyone to take oaths, not only Muslims. Yet for that purpose he calls the Venetian notary to witness the pledge, who holds the Gospels up while the Genoese swears on them. The defendant makes it easy this time for the judge: he acknowledges the validity of the plaintiffs' claims, after which the häjib makes a decision "by virtue of his office." Although formally couched in the procedural rules of the $\operatorname{shari}^{-c} a$, the nature and scope of the justice dispensed clearly evokes the spirit of siyāsa. As at the $q \bar{a} d \bar{l}$ courts, the burden of proof is cast on the oath rather than on the written document. Yet the hājib has allowed a Latin notary to directly collaborate in the production of proof to be used in a siyassa session. Proceedings are recorded and translated by the Muslim dragoman in the presence of both parties and the notary. In exchange, the Venetian clerk draws up his own Latin deed in front of the same dragoman and two Venetians. In this way, the outcome of a single juridical act is conveyed to both legal systems. ${ }^{93}$

The participation of Venetian scribes in the siyassa trials, together with the testimonial role of bilingual simsārs, the borrowing of legal concepts, and the way courts enforced each other's decisions and were selected across boundaries, were all responses to the specific problems of dealing with diversity. The instances of legal cooperation examined so far answer the question posed at the beginning of this paper: legal relations and collaboration went far beyond the range of tolerance and coexistence, but required adjustments in procedural matters and involved a common notarial culture facilitating transactions between strangers.

93 ASVe, CI, N, B. 230, Notary N. Venier, f. 10v-11r, 12 Feb. 1419. 
All too often legal systems are believed to have been kept fundamentally separated until colonization, where Islamic law maintained the biases against non-Muslims and its main formalist traits. Yet legal relations under the Mamluks introduce a hiatus in the teleological vision of a nineteenth-century "modernization" of law, with the inevitable adoption of Western legal principles and codification, such as the article 1736 of the Ottoman Majalla that gave recognition to written documents. The imperceptible, yet significant shift represented by the transition from mazālim to siyāsa shows that medieval societies had their own way to manage diversity and mixed cases, and handled legal norms in ways compatible with the necessities of conflict resolution. The Mamluks did this without allowing anyone to bypass Islamic courts and without really challenging the $\operatorname{shari~}^{-} a$ system of norms. Yet legal change did not follow a gradual, predictable pattern, but was instead contingent and circumscribed to the specific historical setting of medieval exchanges. Indeed, siyāsa courts were not enhanced, but dismantled by the Ottomans, who instead reinstated a more traditional version of royal justice. ${ }^{94}$

The expansion of siyāsa jurisdiction over foreigners tells us much about the pragmatism of Islamic law in premodern times. Conversely, the Western idea that clerks were "public persons," enabled to produce public documents by virtue of an imperial nomination, conveyed a great deal of formalism, and Frankish notarial activity was indeed sustained by a number of intertwined legal fictions.

The notarial casebooks record the remarkable, yet unexpected, emergence of these Islamic courts as an institution capable of enforcing justice not only in mixed cases, but also among Latin Christians. By turning from legal theory to the mixed trials described in this article, we can see how an institution issued from an Islamic legal background consolidated to settle disputes between strangers. Siyāsa justice, it should be noted, emerged even where such an institution was undesired, and it grew out of an unfavorable juridical tradition.

\footnotetext{
${ }^{94}$ Haim Gerber, State, Society, and Law in Islam: Ottoman Law in Comparative Perspective (Albany: State University of New York Press, 1994), 69; Michael Ursinus, Grievance Administration (Sikayet) in an Ottoman Province: the Kaymakam of Rumelia's 'Record Book of Complaints' of 1781-1783 (New York: Routledge, 2004), 1-47; Fuess, "Zulm by Mazālim?," 141.
} 
Abstract: This article describes how Islamic and Frankish legal devices complemented each other and were even combined to settle disagreements in the late medieval Middle East. For this purpose, it focuses on two legal institutions that provided responses to the biases of Islamic law against non-Muslims and to the prejudices of Franks against the local law. The first are the notaries sent to the Mamluk cities by the Venetian government to draw up legal documents and to support the transactions of Venetian merchants. The second are the new royal or siyāsa courts implemented by the sultans, where justice was dispensed by government officials instead of by traditional judges, or qā the article discusses, in a comparative manner, what constituted proof for Christians and Muslims, whether minorities could bear testimony or not, and how notaries and judges dealt with unbelievers. A common notarial culture, together with the expansion of siyāsa jurisdiction over the affairs of foreigners, brought about a much deeper legal interplay than has previously been understood. Ultimately, it is argued that Mediterranean medieval societies had evolving attitudes toward justice and diversity, and approached their own legal traditions in ways compatible with the conflict resolution, while constantly borrowing legal concepts about difference from each other. 